\title{
Determination of Mosque Funds by Indonesian Law Towards the Development of People: Case Study Mosque Raya Ahmad Yani Manado, Indonesia
}

\author{
Deicy Natalia Karamoy' \\ Fakulty of Law University of Sam Ratulangi
}

\begin{abstract}
,
This paper aims to analyze the practice of Indonesian Law in managing funds to finance the management of the mosque. The mosque made as a case study is Ahmad Yani Manado mosque. To determine the management of the mosque funds to be good, controlled and in accordance with the rules, the management must comply with the applicable rules and regulations. Therefore, the objective of this study is to identify the management of the mosque funds in Manado according to the Law. The important thing to be aware of in managing is the management of the Fund that is human. Whereas the law in charge of fund management is contained in Law Number 16 of 2001 on Fondation, Law Number 38 Year 1999 regarding Zakat and Law Number 41 Year 2004 about Waqf. To investigate, this study was conducted by qualitative study design and data analysis in descriptive form. The findings of the study are generally the management of Ahmad Yani Mosque Raya in Manado still done in conventional and traditional ways. This is due to lack of awareness or lack of awareness of mosque managers on the management of funds and mosque institutions. Therefore, it should be welcomed to the management of the Mosque Raya Ahmad Yani in Manado to enhance the management of the fund and the management of Manado. It is also hoped that it will also be able to propose to the institution of the mosques in other mosques in mosques, in order to further improve the management of financially legitimate mosques.
\end{abstract}

DOI: $10.7176 / \mathrm{JLPG} / 82-08$

\section{BACKGROUND OF RESEARCH}

In Islamic teachings, the mosque has a high status, it is placed as God's property and is called Baitullah (House of God). This is as affirmed by Allah in the Qur'an of al-Jin verse 18: And surely the mosques belong to Allah, so do not call anyone in it with Allah. Then the Prophet said: Indeed the houses of Allah on earth are mosques, indeed the right of God to glorify those who visit him in the mosques (HR. Thabrani) (Hidayat T, 2000).

To be able to fully implement the role and function of the mosque at this time, it should also be known how the mosque was functioned during the time of Prophet Muhammad. Among the roles and functions of the mosque at that time was a place of worship, as a meeting place, as a place of consultation, as a place of social activity, as a place of treatment for the sick and as a place of pilgrimage and preaching of Islamiyah (Ismail \& Castrawijaya, 2010).

Therefore, in order to maintain the role of mosque is so great, especially in the process of building a congregation, a mosque management system is a professional and responsible in carrying out its duties, thus enabling the prosperity of the mosque.

Whereas the institution that manages the mosque is the Takmir Mosque Institution, they are appointed by the government and are responsible for the mosque funds. Mosque financial management is one of the key issues that attracts the attention of many. Good financial management practices are not only assessed in terms of recording and reporting of financial transactions but also how to obtain and manage funds effectively.

According to data from the Ministry of Religious Affairs (2010), there are more than 700 thousand mosques in Indonesia and it is the largest in the world. This large number is expected to cause problems in the management of mosques, particularly in the management of funds. Therefore, it is required by law to regulate the mosque management institution.

Managing mosques at this time requires management knowledge and expertise, therefore the mosque manager (Takmir) should be able to adapt to the changing times. To achieve good mosque management requires serious planning and arrangement, excavation and assessment in accordance with Islamic religious values directly from two Nash sources: The Qur'an and the Hadith (Abbas J.A, 2006).

Referring to the decision of the IV Council of the Mosque of the Indonesian Mosque, the management of the mosque should be well managed and professional, in accordance with the principles of modern management. The management of the mosque must formulate the concept of mosque management since its vision, mission, planning and strategic measures. It is to increase the faith, taqwa, noble character, and the intelligence of the ummah, and the achievement of a prosperous justice justified by Allah SWT.

Ayub (1996) emphasizes that every mosque manager should be able to compile financial reports such as how money is entered, collected and used. Then the reports were written and arranged regularly to be informed to the pilgrims during the Friday prayers. 
In addition, in Indonesia many mosque managers do not know their worshipers, as they do not have official data from the pilgrims. Therefore, all congregation members of a mosque should be required to register. It is important to know the true potential of the people, including their socio-economic conditions. The above is not just for the collection of funds, but also to know any member of the pilgrims who are entitled to zakat and anyone who is urgent to help improve his / her standard of living. By listing, it will facilitate the planning of the economic development of the prosperity, thus the function of the mosque as the center Social worship and community development can be fully managed (Ahmad Sutarmadji, 2010).

The Governing Institution of Takmir mosques in Manado according to the statute of the foundation is governed by a religious institution (Commission) comprising the Executing Agency, Board of Trustees and Supervisory Commissions with a 3-year lead time.

In Manado, the management of the mosque in terms of fund management has not been fully practiced following the existing rules, this will certainly cause various problems. Managers do not understand the concept of leadership that has the vision and mission to develop and implement strategic measures to improve the wellbeing of the members of the congregation (Domu, 2011).

Under the above mentioned law, the law referred to in this study is the Law (Law) Number 16 of 2001 on The Foundations, Law Number 1 of 2004 on Waqf and Law Number 38 Year 1999 on zakat management. As stipulated in Clause 1 (1) of Law 16/2001, the foundation is a legal entity comprising wealth disposed of in accountability reports and established for social, religious and humanitarian fields.

Thus, according to the Indonesian law of Mosque management and funds consisting of fixed and irregular contributions as well as the construction of the Mosque, all are under the control of the Law (Law) Number 16 of 2001 which is about the Foundation. Similarly, fund management covering zakat, infak and alms funds, is under the control of Law No. 38 of 1999 on Zakat Management. And in the event of irregularities causing a person to be convicted by the court will be referred to civil law.

With the above, this paper will be divided into 5 (five) sections of the discussion. Among them are background studies, research methods, analysis of mosque fund management analysis, Mosque Raya Ahmad Yani fund management and conclusions.

\section{RESEARCH METHOD}

The method of this research study gathering information from respondents is an in-depth interview. Respondents for this study consist of legal experts and management of mosques in Manado.

For primary research secondary data is obtained from the data of Law (Law) Number 16 of 2001 on The Foundation, Law Number 38 Year 1999 on Zakat Management and Law Number 41 Year 2004 on Waqf.

Research analysis will use descriptive analysis to analyze this investigation. Research will center on the law on the management of the mosque funds with the case of Mosque Raya Ahmad Yani in Manado.

This research findings will analyze the relationship between the foundations of the foundations, zakat and waqf on the case study, so that the laws and weaknesses can be identified. It is hoped that it can be used as a formulation for human resource management under the Islamic law. It is hoped that the analysis will get a backup of the mosque fund management and further research recommendations.

\section{ANALYSIS OF MANAGEMENT FUND OF MOSQUE}

In this section we will also analyze the views of law experts on the management of the mosque funds. It is hoped that in this analysis can find a link between the views of the law and the fund management condition in the case of the study.

\section{Legal Expert's Perspectives on Mosque Fund Management According to Law Number 16 Year 2001 About Foundation of Law}

This research also examines how legal experts view the management of the mosque funds in relation to the Law Number 16 of 2001. Experts interviews on these laws will be analyzed according to their understanding of fund management in accordance with the law, so it is expected get results that can contribute knowledge to current laws.

It can be argued that the way the law of the foundation's fund management is still poorly described in detail. This is because there is no difference between public institutions and religious institutions. However, since the enactment of the laws of this foundation has never been a problem that harms the parties.

In the event of malpractice in the management of funds then the penalties provided are in accordance with the applicable law and may also be referred to criminal, corrupt and civil law.

In its contents the law of the foundation states that the management of the funds and the administrative system will be further explained in accordance with their respective Articles of Association. Similarly, establishing a legal foundation has been arranged in detail, among which must have grants, registered and have a regulatory institution, Founder and organizer of the foundation.

The legal content of the foundation consists of 14 Chapters and 73 clauses. It consists of: general provisions 
(Clauses 1 to 8 Clauses), the foundation of foundation (Clause 9 to Clause 16), amendment of the articles of association (Clauses 17 through 22). Then the announcement of foundation establishment (Clause 24 and Clause 25), wealth or asset (Clause 26 to Clause 27). Whereas the foundation institution starts from the first part of the Board of Trustees (Clause 28 to Clause 30), the second part of which is the Governing Institution (Clauses 31 to 39 ), and the third part of the Watchdog (Clauses 40 to 47 ).

The Foundation's annual report (Clauses 48 to 52), examination of foundations (Clause 53 to Clause 56), then the incorporation of foundations (Clauses 57 to 61). The dissolution of the foundation (Clause 62 to Clause 68), whereas the arrangement of the foundations of the nation is found in Clause 69. The provisions of the sentence are explained in Clause 70, while the transitional provisions found in Clause 71 and Clause 72 and Clause 73 are the closing clauses.

Hence, according to this investigation, the law of the foundation has fully explained how to set up and practice the foundation itself. If you have not yet understood the contents of this law, then the foundation law also has a section on the Explanatory Rules. It clarifies the clause for clause so we can know more in the intent of the verses in the foundation law.

Other matters that are still relevant to the paragraphs in the legal clauses of the foundation may also refer to other laws. The term law is known as juncto. For example, in Clause 26 paragraph 2 (b), it is explained that one of the foundations of the foundation is derived from waqf. However, in Clause 26, paragraph 3 , it is made clear that in terms of wealth waqf, then the provisions of the law of the waqf prevail. In this case may be referred to the Law Number 41 of 2004 on Waqf.

Other examples in the form of penalties, in addition to seeing in Clause 70, if a person violates this rule, then it is possible that the person will be referred to clauses in criminal law or Indonesian Criminal Code (KUHP) and damages may be referred to civil law or the Civil Code of Civil Code (Civil Code).

Expert Views on the Management of Mosque Funds According to Law Number 38 Year 1999 About Zakat The zakat law still needs additional explanations to reinforce existing content. This law still needs details on the assignment of the Zakat Amil Agency and also the way to pay zakat. The penalties in this law need to be added as it is still too lightly given to them to devalue zakat funds.

The content of this zakat law consists of 10 chapters with 25 clauses. Among the contents include, the general provisions beginning from Clause 1 to Clause 3, the basis and purpose of zakat are contained in Clause 4 and Clause 5. The zakat management organization is described in Clause 6 to Clause 10. Then zakat collection is described in Clause 11 to Clause 15.

While zakat utilization is described in Clause 16 and Clause 17. Zakat supervision is also contained in Clause 18 up to Clause 20. Whereas the penalty for the offense is set out in Clause 21. Other provisions are set out in Clause 22 and Clause 23, while the provisions of the transitional and cover are explained in Clause 24 and Clause 25. This law also has an Explanation Order in the next section.

In this research, this law is less effective in the management of zakat, as many of the verses have not explained in detail the duties and responsibilities of the Amil Zakat Agency. Financial management and other zakat are also not explained in full detail. So this will affect how to collect and distribute the zakat itself.

There is a verse that explains that the Amil Zakat Agency can also accept the property other than zakat which is enshrined in Clause 13, among which is infak, alms, will and kaafar. Certainly his duties and responsibilities will refer to other laws.

Penalties in this law are also very low, allowing for financial irregularities. With a fine of only Rp. 3,000,000 or equivalent to RM 900 and a 3-month prison sentence, making the law seem so light. However penalties due to financial irregularities may also be referred to other laws such as anti-corruption law and criminal law in Indonesia.

Expert Views on Mosque Fund Management According to Law Number 41 Year 2004 About Endowment Generally, the content of this waqf law is completely good. There are only a few explanations related to the administration of waqf. But the interesting thing here is the existence of money waqf as the kind of waqf currently in demand. This is due to the fact that the land in today's land is difficult to manage and is available from waqf of money. Land ownership remains one of the major problems in Indonesia (Sihombing, 2010). Until the money is easier to make waqf. Therefore, in Manado waqf is practiced by the Ministry of Religion of North Sulawesi Province. Waqf has a lot to do about administration as it has been said by Prof. Jahya bin Smith and Maria Ulfah.

Viewed from the legal content of waqf, it consists of eleven chapters and 71 clauses. It begins with the general provisions beginning from Clause 1, then the waqf policies comprising ten parts beginning from Clause 2 to Clause 31. The sections include, general parts, purposes and functions of waqf, waqf, wakif, nazhir, property waqf, waqf pledge, waqf property provision, waqf with wills and waqf of moving objects in the form of money.

Furthermore, with the registration and announcement of the waqf property are described in Clause 32 to Clause 39. It is further explained the change in status of waqf property which covers Clause 40 and Clause 41. Whereas the management and expansion of waqf property are described in Clause 42 up to Clause 46. 
The Indonesian waqf institution is described in Clauses 47 to 61 . Whereas for the settlement of the waqf dispute is explained in Clause 62. For construction and supervision is explained in Clauses 63 to 66. While the criminal and punishment provisions are set out in Clause 67 and Clause 68 . The legal content of waqf is closed by the transitional provisions and cover provisions stipulated in Clauses 69 to 71.

In the above explanation it is known that the law is already fully good. Additional explanation can be explained in the administration and management of Nadzir later. Hence, in the sentence of judgment, has been detailed in accordance with criminal and administrative laws administered by civil law and the law of the foundation.

Based on the views and research of secondary data of the law, it is found that the law of the foundation is generally good. Only a few parts can not be described in detail about the management of funds considering that it is described in Clause 14 foundation laws. Furthermore, the management of funds in the zakat law should be made a little improvement, especially for the administration, the management of zakat amil zakat, the distribution and punishment of so little that do not administer the zakat properly.

While the law of waqf has been described in this law. Only waqf money still needs further clarification. Nadzir also needs to be explained in his administration.

\section{MANAGEMENT FUND OF MOSQUE AHMAD YANI}

After knowing the analysis of the views on the law, research will be conducted on the case study of Mosque Raya Ahmad Yani. This is to ascertain, the process and procedure of law practice that has been done by mosques in Manado which in this case is seen in the case of the Mosque Raya Ahmad Yani Manado.

It is the largest mosque in North Sulawesi. Standing under the Yayasan Ahmad Yani Manado. It was first built in 1966. It was built with the upgrade in 1998 in October marked with the first stone placement. The capacity of the mosque can accommodate 4,000 people in one worship. The Mosque's construction funds are derived from donations, religious institutions and Non-Governmental Organizations (NGOs).

At the time of building the mosque building is still very simple. The foundation only uses rocks because the area is a coastal area. Floors are built out of boards, and part walls are still boards. In parallel with the travel time, and the people began to crowded, the mosque was upgraded. The Mosque Building is one of the largest and largest buildings in Manado. The Construction of the Mosque Raya Manado is under the supervision of the Takmir Institution of Manado Raya Mosque which later became the mosque manager.

The Takmir Institution of the mosque consists of 6 ( six) board members, with their respective posts. Among his posts are chairman, vice-secretary, secretary, vice secretary, treasurer and vice-treasurer. While in the management of the notorious Mosque Raya Ahmad Yani, there are also some who take care of development, zakat, education, youth and adolescence and femininity.

\section{SOURCE OF MOSQUE FUNDS}

The funds entered in the Mosque Raya Ahmad Yani are derived from personal contribution, government and private donations, alms, infaq and zakat.

The funds entered into the mosque are every Friday prayer, the data is derived from January 2012 until March 2012 is obtained from community donations, infaq and alms of Rp. 3,200,000. So that the amount of funds collected in Mach 2017 is Rp. 10,000,000.

\section{Save}

To date, existing funds are not deposited in the bank account but by the treasurer. This is done by the mosque manager considering that until now, the mosque is still under construction.

Funds deposited by the treasurer by field data until March 2017 are Rp. 20,000,000. This fund is the balance used for the construction of the Mosque Raya Ahmad Yani.

\section{Applied}

Routine payments made by this mosque for Friday prayers, electricity bills, water and other necessities. The following is the use of funds from January 2017 to March 2017. Among the average monthly usage of money is:

The Imam Mosque payment is Rp. 1,000,000.

Electric and water bills are Rp. 400,000

Cleanliness was Rp. 400,000

\section{Record}

To date, records are only known by the chairman and treasurer. No records were communicated to the pilgrims or in the mosque board. The record of the funds is monitored by the chairman and community of the mosque. 


\section{ANALYSIS OF CASE STUDY}

According to an interview with chairman Mohammad Yusuf, the mosque finance has not been a problem. Because this mosque is the Great Mosque and all guests and religious people of the Islamic faith will worship in this mosque, making it easier to collect donations.

According to Tamsil Permata, there has been no problem with the administration of the mosque. The mosque takmir management runs well because it does not have mosque agendas that have a big influence on management. This makes the management of the mosque run smoothly.

The treasurer of the mosque Mr. H. Adi Rassan in an interview said that since the mosque was still under construction, the remaining funds of the mosque were kept privately by him. This is to facilitate the use of funds for the purchase of building materials. While the fund's record was not disclosed to the pilgrims and billboards is due to funding requirements for construction.

Referring to the above data, it is found that the management of this mosque has not been fully implemented in accordance with the law. The Supervisory Institution and Board of Trustees under the law of the foundation are not found in the management of the Mosque Raya Ahmad Yani, until the practice of management can not be carried out in full. In the case of finance that includes collection, save, use and record is not fully run and managed properly.

This mosque has no Mosque Policy Estimates. As such, management policies, practices and management rules within this mosque can not be fully functioned and in accordance with Clause 14 of Law Number 16 of 2001 on the Foundation.

There is no clear record so that the incoming funds can not be properly accounted for. Indeed in the field investigation can be seen the condition of the mosque building that has entered the 80 percent completion stage. However, fundraising records should also be made public. According to Article 26 of Law No. 16 of 2001 on the foundation of the foundation, the proper funds of the mosque should also be separated and explained in accordance with the sources of the fund. The mosque manager did not make a good explanation of the sources of funds collected or admitted to the mosque.

Financial reports are also not made by Ahmad Yani's mosque management, though it should be reported every three months and every year at the end of each year. Whereas pursuant to Clause 48 to Clause 52 of Law no. 16 of 2001, that the manager is obliged to create and keep records or records containing financial documents and data of financial administration supporters.

Table 1. Management Fund of Ahmad Yani Mosque

\begin{tabular}{|c|c|c|c|c|c|c|c|c|}
\hline \multicolumn{9}{|c|}{ MOSQUE AHMAD YANI } \\
\hline \multicolumn{3}{|c|}{ FONDATION } & \multicolumn{4}{|c|}{ MANAGEMENT FUND } & \multirow[b]{2}{*}{ ZAKAT } & \multirow[b]{2}{*}{ WAQF } \\
\hline $\begin{array}{l}\text { Supervisory } \\
\text { Institution }\end{array}$ & $\begin{array}{c}\text { Takmir } \\
\text { Institution }\end{array}$ & $\begin{array}{l}\text { Institution } \\
\text { Advisory }\end{array}$ & Collects & Savings & Uses & Records & & \\
\hline Non & $\begin{array}{l}\text { Have, } \\
\text { There are } \\
\text { six } \\
\text { members } \\
\text { of board } \\
\text { Takmir }\end{array}$ & Non & $\begin{array}{c}\text { Have, } \\
\text { Routine } \\
\text { Friday, } \\
\text { Personal } \\
\text { donation, } \\
\text { Government } \\
\text { donation, } \\
\text { Particular } \\
\text { donation, } \\
\text { charity, } \\
\text { Infak, } \\
\text { zakat } \\
\end{array}$ & Non & $\begin{array}{c}\text { Have, } \\
\text { Imam, } \\
\text { Electric } \\
\text { bill, } \\
\text { Water bill, } \\
\text { cleanliness }\end{array}$ & $\begin{array}{c}\text { Internal } \\
\text { Board }\end{array}$ & $\begin{array}{l}\text { Fitrah, } \\
\text { Ramadhan } \\
\text { donation }\end{array}$ & Non \\
\hline
\end{tabular}

\section{CONCLUSION}

Need more clarification on the Foundation's Elucidation Rules, which overlaps zakat and waqf laws, by the government or the parliament. In addition, recommending the creation of the Religious Foundations Law separated by the Commonwealth Law and the Zakat Act also need to be further detailed, especially in the case of zakat institutions.

The way funds are funded in the law of the foundation is not fully explained. Foundations must have a grant, be registered and have a Board of Trustees, Governing Institution of the foundation. In the case of the founding of the foundation, the law has already elaborated by making its Articles of Association respectively in accordance with the purpose of the foundation itself. Other matters that are still relevant to the paragraphs in the legal clauses of the foundation may also refer to other laws. The term law is known as juncto.

Given the above, it appears that the fund management in case studies in Manado is still done in conventional and traditional ways. This is due to lack of understanding or lack of awareness of mosque managers on the 
management of funds and mosque institutions. Therefore, it is necessary to welcome the management of the mosques in Manado to improve the management and management of the mosque in Manado.

Fund management, collection, storage, use and records should be further enhanced in mosques in Manado. Furthermore, for the Supervisory Board of the Takmir Mosque is also more able to improve understanding and knowledge about fund management through management courses or other educational courses. So that the management of the mosque to reach the soft management can be realized.

\section{BIBLIOGRAFI}

Aaker, D. A, Kumar, V. \& Day, G. S. (1999). Marketing Research (6 ${ }^{\text {th }}$ ed). New York, John Wiley \& Sons Inc. Abdurrahim dan Mubarak, M.A, (2002). Zakat Dan Peranannya Dalam Pembangunan Bangsa Serta Kemaslahatannya Bagi Umat. Jakarta. Surya Handayani Pratama. Jakarta

Abbas J. A. (2006). Islamic Perspective On Management and Organization, IIUM Journal of Economics and Management.

Albehairi, A.A. (1988). Religious Orientation and Fear of Death among Muslim and Christian Individu, Kingston, University of Rhode Island.

(1997). Development of Muslim Religiousity Scale, Ph.D Thesis, University of Rhode Island.

Ali, Chaidir. (1991). Badan Hukum, Alumni, Bandung.

Ali, M. D. (1988). Sistem Ekonomi Islam Zakat dan Waqf. Jakarta. UI Press.

Agung, W. D, (2003). Media Informasi Untuk Sosialisasi dan Pencitraan LPZ. Makalah Pada Musyawarah Nasional Forum Zakat. Balikpapan.

Anshori, AG., (2006). Hukum dan Praktik Perwaqfan di Indonesia, Yogyakarta: Pilar Media Ash Shiddieqy, T. M., (1999). Pedoman Zakat. Semarang. PT Pustaka Riski Putra.

Avenzora, A., (2003). Parameter Kemiskinan Dalam Tinjauan Konsumsi \& Pendidikan. Makalah pada Seminar Garis Kemiskinan Indonesia, Forum Zakat, Jakarta.

Ayub, Mohammad E. (1996). Manajemen Mosque; Petunjuk Praktis Bagi Para Pengurus/Penulis, Cetakan 1, Guna Insani Press, Jakarta.

Chaidir, A., (2005). Badan Hukum, Alumni, Bandung

Chatamarrasjid, (2000). Tujuan Sosial Yayasan dan Kegiatan Usaha Bertujuan Laba, PT. Citra Aditya Bakti, Bandung.

, (2006). Badan Hukum Yayasan, Edisi Revisi, Citra Aditya Bakti, Bandung

Cole, R.E. (1973). "Functional Alternatives And Economic Development: An Empirical Example Of Permanent Employment In Japan", American Sociology Review, Vol. 38, pp. 424-38.

De Belder, R.T. and Khan, M.H. (1993). "The Changing Face Of Islamic Banking”, International Financial Law Review, Vol. 12 No. 11, pp. 23-6.

Domu, H., (2011). Kesadaran Memberi Zakat Rendah, Harian Manado Post, 28 April, ms. 7. El-Bantanie, M. S., (2009). Zakat, Infak dan Sedekah, Salamadani Pustaka Semesta, Bandung.

Endot, S. (1995). The Islamisation Process in Malaysia, PhD Thesis, University of Bradford. Gondo, Gambiro, (2011). DPR Setujui RUU Zakat, Infak dan Sedekah (ZIS) Menjadi Undang- Undang, www.usdetiknews.com/read/2011/11/01

Gunawan, W., (2002). Yayasan di Indonesia Suatu Panduan Komprehensif, Elex Media Komputindo, Jakarta.

Hidayat, T., (2000), Bangunan Mosque Menurut Al-Quran dan Hadits, Tesis Magister Program Pascasarjana FTSP-ITS, Surabaya.

Irawan, P. (2007). Penelitian Kualitatif dan Kuantitatif Untuk Ilmu-Ilmu Sosial, Departemen Ilmu Administrasi Fakultas Ilmu Sosial dan Ilmu Politik, Universitas Indonesia.

Ismail, A. S. \& Castrawijaya, C., (2010). Manajemen Mosque, Angkasa, Bandung.

Kamil Md.Idris, (2007). Kesan Persepsi Undang-Undang dan Penguatkuasaan Zakat Terhadap Gelagat Kepatuhan Zakat Pendapatan Gaji, Jurnal Rekayasa, 2 (1). Malaysia

Khan, M.A., (1991). "The Future Of Islamic Economics", Futures, Vol. 23 No. 3, pp. 248-61. Larasati, N. (2010). Analisis Peranan Undang-Undang Nomor 16 Tahun 2001 dan Undang- Undang Nomor 28 Tahun 2004 Tentang Yayasan Terhadap Pendirian Yayasan Islam, Tesis Magister Notariat, Universitas Indonesia.

Mahamood, S. M., (2007). Pembentukan Dana Waqf Menurut Perspektif Syariah Dan Undang-Undang Serta Aplikasinya Di Malaysia, Jurnal Syariah 15 : 2, Malaysia.

Moleong, L. J, (2000). Metoda Kajian Kualitatif, PT. Remaja Rosdakarya, Bandung

Mohamed Ali Haji Atan (t.t), Pengurusan Mosque: Pengalaman Republik Singapura, atas talian: static.scribd.com/docs/2ot21r5rphyxf.pdf, tarikh diambil 15 Jun 2011.

Mohamad Tajuddin Mohamad Rasdi, 1962-.(1999). Peranan, Kurikulum dan Reka Bentuk Mosque Sebagai Pusat Pembangunan Masyarakat, UTM, Malaysia

Muis A., (1991). Yayasan Sebagai Wadah Kegiatan Masyarakat (Suatu Tinjauan Mengenai Yayasan Sebagai Badan Hukum Dalam Menjalankan Kegiatan Sosial, Medan : Fakultas Sumatera Utara 
Neuman, W. L. (2006). Social Research Methods: Qualitative and Quantitative Approaches (6 ${ }^{\text {th }}$ ed). Allyn and Bacon, Boston.

Nindyo P., (2002). Reformasi Yayasan Perspektif Hukum dan Manajemen Kedudukan Hukum Yayasan di Indonesia, Penerbit Andi, Yogyakarta

Nugraha, B. J., (2006). Pelaksanaan Pendirian Yayasan Berdasarkan UU No. 16 Tahun 2001 dan No. 28 Tahun 2004 di Denpasar, Tesis Magister Kenotariatan, Universitas Diponegoro.

Palmawati, T., (2004). Zakat dan Negara, Studi Tentang Prospek Zakat Dalam Meningkatkan Kesejahteraan Masyarakat Dengan Berlakunya UU No. 38 Tahun 1999 Tentang Pengelolaan Zakat, Disertasi Doktor, Universitas Indonesia, Jakarta.

Panggabean, H.P., (2002). Kasus Aset Yayasan dan Upaya Penanganan Sengketa Melalui Alternatif, Pustaka Sinar Harapan, Jakarta.

Qahaf, M, (2005). Manajemen Waqf Produktif, Jakarta: Khalifah

Qardhawi, Y., (2002) Hukum Zakat. Terj. A. Lira Antar Nusa

Raharjo, H., (2009). Hukum Perusahaan, Pustaka Yustisia, Yokyakarta.

Rido. R., Ali., (2001). Badan Hukum dan Kedudukan Badan Hukum Perseroan Perkumpulan, Koperasi, Yayasan, Waqf, Penerbit Alumni, Bandung.

Sabitha Marican, (2006). Kaedah Penyelidikan Sains Sosial, Prentice Hall, Selangor, Malaysia Sat Dee. (2011). Mosque Management: Introductory Analysis into The Rerpublic of Penang Election, http://satdthinks.blogspot.com/2011/06/mosque-management-introductory-analysis.html

Setiawan, (1990). Tiga Aspek Yayasan, Varia Peradilan, Tahun V, No.55, Jakarta.

Shaikh Ali Mohamad Mokhtar, (2003). Peranan Mosque Dalam Islam, Yayasan Dakwah Islamiah Malaysia, Kuala Lumpur.

Sigit H.YB, (2002). Akuntabilitas Yayasan, Andi,Yokyakarta.

Singarimbun, M dan Effendi, S. 1997. Metode Penelitian Survai, Jakarta: LP3ES

Soeroredjo, H., (1989). Status Hukum dari Yayasan dalam Kaitannya dengan Penataan Badan-badan Usaha di Indonesia, Makalah. 15 Desember 1989.

Soemitro, R., (1989). Yayasan, Status Hukum dan Sifat Usaha, Jakarta, 15 Desember 1989. Suhardiadi, Arie K. M., (2003). Hukum Yayasan di Indonesia, Abadi, Jakarta

Supramono, G., (2007). Kedudukan Perusahaan Sebagai Subjek Dalam Gugatan Perdata Di Pengadilan, Penerbit : Rineka Cipta, Jakarta. , (2008). Hukum Yayasan di Indonesia, Rineka Cipta, Jakarta

Supardi dan Amrudin T. (2001). Manajemen Mosque dalam Pembangunan Masyarakat, Optimalisasi Peran dan Fungsi Mosque, UII Press, Yogyakarta.

Syawie, H., (1993). Aspek-aspek Hukum Mengenai Yayasan di Indonesia, Varia Pendidikan, Tahun IX, No. 9, Jakarta.

Undang-Undang Republik Indonesia Nomor 38 Tahun 1999 tentang Pengelolaan Zakat. Undang-Undang Republik Indonesia Nomor 16 Tahun 2001 tentang Yayasan Undang-Undang Republik Indonesia Nomor 41 Tahun 2004 tentang Waqf

Untung, B., (2002) Reformasi Yayasan dalam Perpekpektif Manajemen, Andi Yogyakarta. Wijayakusuma, K. M., \& Yusanto I., (2002). Pengantar Manajemen Syariat, Khaerul Bayan,Jakarta

Yahya, Y. (2006). Pengantar Manajemen, Graha Ilmu, Jakarta. 